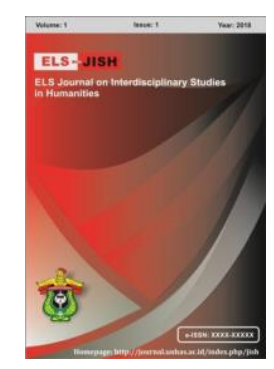

ELS-JISH

ELS Journal on Interdisciplinary Studies on Humanities

Volume 3 Issue 2, 2020

ISSN (print) : 2621-0843

ISSN (online) : 2621-0835

Homepage : http://journal.unhas.ac.id/index.php/jish

\title{
The Analysis of Denotative and Connotative Meaning in Ariana Grande's Song Lyrics: A Semantic Study
}

\author{
Desy Riana Pratiwi ${ }^{1}$, Lia Maulia Indrayani ${ }^{2}$, Ypsi Soeria Soemantri ${ }^{3}$ \\ 1․esyrianapratiwi@yahoo.co.id
}

\begin{abstract}
The meaning in language is indeed diverse in types, one branch of linguistics that studies about meaning is semantic science. Semantic referred to as the study of meaning, this research aims to analyze denotative meanings and connotative meanings contained in song lyrics, an expression of one's feelings or ideas usually expressed through song lyrics. The song chosen for this research data is Ariana Grande's song entitled "God is a woman". This analysis used a qualitative descriptive method which is a method that aims to analyze everyday phenomena and analyze the use of words including finding meaning contained in song lyrics. To answer this analytical question, used the main theory from Geoffrey Leech about semantics. The results of this analysis are more connotative meanings compared to denotative meanings in Ariana Grande song lyrics, this study found three connotative meanings and two denotative meanings. The number of connotative meanings and denotative meanings is not too much different, but connotative meanings are more numerous because this song contains many meanings that are not actually.
\end{abstract}

Keywords: Denotative Meaning, Connotative Meaning, Semantics, Song.

How to cite: Pratiwi, D. R., Indrayani, L. M., \& Soemantri, Y. S. (2020). The Analysis of Denotative and Connotative Meaning in Ariana Grande's Song Lyrics: A Semantic Study. ELS Journal on Interdisciplinary Studies in Humanities, 3(2), 231-235. DOI: 10.34050/elsjish.v3i2.9994

\section{Introduction}

Language is the main communication tool in everyday human life, the point is to convey messages and ideas contained in a sentence and word that has meaning and contains various meanings. Communication in languages is divided into two, namely through oral communication and written communication. Usually oral communication is in speeches, interviews and others, while written communication is found in writings such as news magazines, advertisements and slogans. Riemer (2010) according to him, meaning is the most important aspect for language learning, without the capacity to express meaning language loses one of its important aspects. In this analysis the author will discuss the meaning that exists from a semantic perspective, namely denotative meaning and connotative meaning contained in

1,2,3 Universitas Padjadjaran, Indonesia. 
song lyrics. Song lyrics are often used by the creator as an intermediary to convey the contents of thoughts and feelings, song lyrics are made with various types of language styles. Songwriters see music as something that symbolizes their personal characteristics (Moon et al., 2006). Here the writer chooses the analysis data from Ariana Grande's song, as it was known on July 13, 2018 Ariana Grande released a song called "God is a Woman" in the title and the lyrics have hidden meanings and reap a lot of controversy, one of which is Ariana allegedly defaming God with the song, this analysis aims to see other meanings contained therein so that listeners can better understand the message stored in the lyrics of the song. Semantic is a branch of linguistics that studies about meaning. According to (Leech, 1981) semantic is the study of meaning and is the center of communication in language. Semantics has a type of meaning that is divided into seven parts, but in this analysis the author limited and took only two parts of meaning, namely denotative meaning and connotative meaning. According to (Sari \& Kusumawardhani, 2016) the difference between denotative meanings and connotative meanings is denotative meanings that are real meanings in accordance with the dictionary, directly interpreting words, phrases and sentences accordingly. However, connotative meaning is the meaning of words, phrases and sentences that are in accordance with suggestions or beyond the original meaning. According to (Mangewa, 2012) said that the denotative and connotative meaning are both based on the relationship between meaning and words. According to (Fromkin et al., 2017) we will know a lot about language when we understand about meaning, such as whether a word has meaningful or meaningless, when a sentence has meaning or not and has ambiguous meaning or not. When understanding the meaning in our language also finally know where the direction and purpose of a sentence.

This analysis uses the main theory from (Leech, 1981) says, semantics is the study of meaning and as the center of communication in language. In line with his opinion (Yule, 1985) said, semantic is the study of meaning in words, phrases and sentences. In semantic analysis the focus is on the meaning of what appears in the conventional word, aiming to explain what humans know. (Goddard, 2011) said semantics can also be called a linguistic center because through semantics we understand the nature of language and the ability of human language. According to (Riemer, 2010) the way we use the concept of meaning in language is important because it gives us a starting point for the description of semantic theory. Semantic helps us easily express meaning in everyday language. The meanings in semantic are divided into seven types of meanings namely denotative meanings, connotative meanings, social and affective meanings, reflective and collocative meanings, and associative meanings. But in this analysis the writer only takes two meanings, denotative meaning and connotative meaning.

According to (Leech, 1981) conceptual meaning or meaning that can also be called denotative or cognitive meaning is the most important factor in the language of communication, this meaning still refers to the basic reference or can also be referred to as pure meaning in a speech of the language. Denotative meaning is also the meaning that is in accordance with the experience, what is seen and heard so it can be concluded that the denotative 
meaning is the real meaning or meaning that is in accordance with the dictionary. An example of a denotative meaning is the known meaning of the word woman can be specified as human, female, girl and adult. All that can be concluded in accordance with the pure meaning of women.

Connotative meaning is the meaning that does not go directly to the intent or something, in other words this meaning exceeds the conceptual meaning itself, connotative meaning is often referred to as meaning that is not actually. According to (Leech, 1981:12) says "connotative meaning is the communicate value and expression has a virtue of what it refers to, over and purely conceptual content" so that it can be interpreted that connotative meaning is the meaning that gives rise to more expressions based on what is meant more than the conceptual meaning itself or its denotative meaning. For example, if we call the word police the connotative meaning refers to the meaning of "strong" and when we say the teacher refers to the meaning of "hero". According to (Masriyah et al., 2019) connotative meaning functions to convey an experience in the real world to be associated with someone's expression when listening and using it. According to (Zuhdah \& Alfain, 2020) the definition of connotation has the meaning of having more meaning. It can be concluded that connotation is a meaning that appears in addition to the meaning of the dictionary or the actual meaning.

Song or song lyrics is an expression of poetry and emotional contents written poetically, the aim is to make the listener feel more what is in the lyrics so that the message conveyed is more felt in the heart. Song lyrics contain a lot of messages to be conveyed to the listener, but not infrequently, the lyrics of the song contain many meanings that are not actually, as in the song God is a Woman, owned by Ariana Grande, listeners must be wondering about the contents of the lyrics, if seen at first glance it means that God is a woman, but when viewed with connotative meaning the meaning of the song's lyrics exceeds the true meaning. Song is closely related to culture, with the experience experienced by the author or others. This song is the same as other songs, it contains an idea and point of view of the writer. the writer is interested in analyzing further and seeing what meaning is contained in the lyrics of this song.

\section{Method}

In this analysis the authors used a qualitative descriptive analysis method, the method used by collecting data and analyzing an object and then described. According to (Creswell, 2014) the qualitative descriptive method serves to describe phenomena that can be found daily, in this analysis the phenomenon is the slogan in an advertisement for an airplane. According to (Nazir, 1985) in his book Research methods, descriptive method is a method in examining the status of human groups, a subject, a set of conditions, a system of thought or even a class of events at the present time. The purpose of this descriptive study is to make a systematic description, picture or painting and the relationship between the phenomena investigated.

\section{Findings and Discussions}


The data taken for this analysis was taken from several lyrics of the song Ariana Grande released in July 2018, the title of this song is "God is a woman

\subsection{The Analysis of Data 1}

\section{My one, when all is said and done you'll believe God is a woman.}

In the data above, the lyrics tell as if what the woman said is true that God is a woman. "God is a woman" in the lyrics above is included in the connotative meaning because the real meaning is not God is a woman who has gender but the woman in the lyrics is described as a god who has more power in love and makes women the center of the world.

\subsection{The Analysis of Data 2}

... and I can be all the things you told me not to be.

In the data above, the lyrics illustrate that this woman seems to be able to grant all the wishes of men, which is likened to God being able to answer all human prayers. The meaning contained in "all the things you told me" is a denotative meaning, because the meaning refers to the real meaning if women or even all types of gender in the world can grant the wishes of others, it does not have to be likened to God. But if it is connected with the whole song lyrics this meaning can be connotative meaning.

\subsection{The Analysis of Data 3}

\section{.. and he see the universe when I'm in company, all in me}

This data tells us that when accompanied by women, you will be able to see the world. The meaning in "the universe when I'm in the company, all in me" is a connotative meaning that is meaning that exceeds the true meaning, in the lyrics are described as if women are the center of the world, when men and women can see the universe and everything is in women. But the truth is that only God is able to possess all of these characteristics.

\subsection{The Analysis of Data 4}

..so baby take my hand, save your soul..

This data tells us that when accompanied by women, you will be able to see the world. The meaning in "the universe when I'm in the company, all in me" is a connotative meaning that is meaning that exceeds the true meaning, in the lyrics are described as if women are the center of the world, when men and women can see the universe and everything is in women. But the truth is that only God is able to possess all of these characteristics.

\subsection{The Analysis of Data 5}

\section{..and boy if you confess, you might get blessed.}

In the data above, Ariana's seems to give orders to the man she likes to confess if women are God. In "you might get blessed" is an invitation sentence, which means it belongs to the denotative meaning because the sentence has the same meaning as the real meaning and does not exceed the actual meaning. 


\section{Conclusion}

The conclusion in the above analysis is that this analysis contains many denotative meanings, or meanings that are not actually. In the lyrics of the song God is a woman, many contain figurative meanings and have meanings that are not true. When viewed with an implied meaning, the sentences written in the song's lyrics describe as if a woman is like a god who can grant all desires, make men dependent, give blessings and make women the center of the world. However, actually if seen from the overall meaning of this song it means that women are likened to God and should have power in a love relationship. Ariana also tells about a woman how to be treated by men. The author hopes that with this research, it can help readers to better understand the types of meaning that exist in language, so that readers will be easier to understand what message is contained in each utterance. Because not everything written and discussed has a real meaning, many also have an implied meaning.

\section{References}

Creswell, J. W. (2014). Research Design: Qualitative, Quantitative, and Mixed Methods Approaches. SAGE.

Fromkin, V., Rodman, R., Hyams, N., Amberber, M., Cox, F., \& Thornton, R. (2017). An Introduction to Language. Cengage AU.

Goddard, C. (2011). Semantic Analysis: A Practical Introduction. OUP Oxford.

Leech, G. N. (1981). Semantics: The Study of Meaning. Penguin Books.

Mangewa, Y. P. (2012). An Analysis on the Denotative and Connotative Meaning of Lyrics of Creed's Songs. AgroSainT, 3(2), 337-337.

Moon, H. R. F. D. of E. R., Knowles, M., \& Moon, R. (2006). Introducing Metaphor. Psychology Press.

Riemer, N. (2010). Introducing Semantics. Cambridge University Press.

Yule, G. (1985). The Study of Language. Cambridge University Press.

Zuhdah, D. R., \& Alfain, S. N. (2020). An Analysis of Denotation and Connotation in Chairil Anwar's Poem. E-Journal of Linguistics, 14(1), 103112. https://doi.org/10.24843/e-jl.2020.v14.i01.p11 